\title{
CHANGING COMPOSITION OF HUMAN CAPITAL: THE CZECH REPUBLIC, HUNGARY, AND POLAND
}

\author{
Byeongju Jeong \\ Michal Kejak \\ Viatcheslav Vinogradov
}
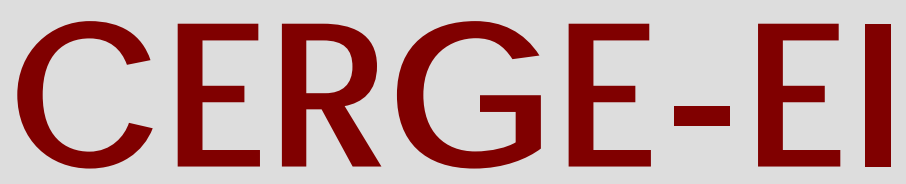

Charles University

CenterforEconomic Research and Graduate Education Academy of Sciences of the Czech Republic Ec onomic s Institute 


\title{
Working Paper Series \\ 248 (ISSN 1211-3298)
}

\section{Changing Composotion of Human Capital: The Czech Republic, Hungary, and Poland}

\author{
Byeongju Jeong \\ Michal Kejak \\ Viatcheslav Vinogradov
}

CERGE-EI

Prague, March 2005 
ISBN 80-7343-041-X (Univerzita Karlova v Praze, CERGE)

ISBN 80-7344-030-X (Národohospodářský ústav AV ČR, Praha) 


\title{
CHANGING COMPOSITION OF HUMAN CAPITAL: THE CZECH REPUBLIC, HUNGARY, AND POLAND
}

\author{
Byeongju Jeong,* Michal Kejak, and Viatcheslav Vinogradov
}

CERGE-EI

POB 882, Politickych veznu 7

11121 Prague 1

Czech Republic

byeongju.jeong@cerge-ei.cz

January 2005

\begin{abstract}
We show that the business education/occupations have expanded and that the technical education/occupations have contracted in the Czech Republic and Poland since 1990. We interpret these changes as an adjustment necessary for their transition to a market economy. We do not find the same pattern in Hungary, which we attribute to its earlier timing of transition. We construct an aggregate model in which labor reallocates in response to changing demand structure. When calibrated to the Czech and Polish data, the model generates a large movement of workers with technical education and experience into business occupations in the early 1990s. The discounted sum of output loss due to the gap between the demand structure and the composition of existing human capital amounts to 20 to 40 percent of 1990 GDP.

V této práci ukazujeme, že od roku 1990 se v České republice a v Polsku skupina lidí, kteří mají povolání a/nebo vzdělání v ekonomických profesích zvětšila, zatímco skupina lidí s technickým povoláním a/nebo vzděláním se zmenšila. Tyto změny interpretujeme jako přizpůsobení nezbytné pro přechod $\mathrm{k}$ tržní ekonomice. V Mad'arsku jsme podobný trend nenašly, což přisuzujeme faktu, že zde přechod proběhl v dřívějším období. Konstruujeme agregátní model, ve kterém se pracovní síla přemístuje v odezvě na měnící se strukturu poptávky. Model, kalibrovaný na česká a polská data, vykazuje velké přesuny pracovníků se vzděláním a praxí v technických oborech do ekonomických povolání na počátku 90. let. Discountovaný součet ztráty výroby z důvodu rozdílu mezi strukturou poptávky a rozložením existujícího lidského kapitálu dosahuje 20 až 40 procent HDP roku 1990.
\end{abstract}

JEL classification: J31; J62; P23; E13

Key words: human capital; composition; occupation; education; mobility; transition

\footnotetext{
* Corresponding author. We greatly acknowledge the contribution of Viliam Druska in the earlier phase of our research. Our research was supported by the grant European Union Phare ACE P97-8085-R. We thank Randy Filer, Stepan Jurajda, Gerard Roland, Fabrizio Zilibotti, and seminar participants at CERGE-EI, ZEI-CEPR Workshop on Labor Markets in Riga, WDI-CEPR Conference on Transition Economics in Portoroz, European Economic Association Congress in Lausanne, and European Association of Labor Economists Conference in Jyvaskyla for helpful comments.
} 


\section{Introduction}

Human capital is not homogeneous: an engineer and an entrepreneur may have the same level of human capital but not the same type. Suppose that in an economy there are many workers with engineering skills but few with entrepreneurial skills, yet the economy demands many entrepreneurs and few engineers. This situation roughly describes the economies of the Czech Republic, Poland, and, to a lesser extent, Hungary in the early 1990s. A key aspect of their transition toward a market economy has been the reorientation of human capital from the technical to the business-serving types. In this paper, we assess its quantitative significance.

Our strategy is to investigate the reallocation of labor along the educational and occupational dimensions. Based on data analysis, we construct an aggregate model with endogenous occupational mobility and quantify the welfare impact of the initial imbalance and the subsequent adjustment in human capital. We emphasize that the changes in human capital that we study are not about the level but the composition. In 1990, the average number of schooling years was 10.1 in Czechoslovakia, 8.9 in Hungary, and 9.5 in Poland. These numbers are comparable to those for the OECD countries, whose average was 9.0 (Barro and Lee 1996). We also abstract from the changes in the composition of human capital within an occupation or within a type of education: a business worker in the new market economy may have different skills from his counterpart in the old command economy although they share a common occupational code. This is a potentially significant omission. Our only defense is that we chose to study a readily quantifiable aspect of the changes in human capital, and that our results represent a low bound of their quantitative significance.

In Section 2, we present the evidence for labor reallocation. In the Czech Republic and Poland, there has been a major shift in education from the technical to the business fields since 1990. Also, the business occupations have expanded while the technical occupations have contracted. These changes were a sort of catching up with the other European 
countries. We do not find the same pattern in Hungary, however, which may be due to the fact that it began its transition to the market economy in the 1980s, earlier than the Czech Republic and Poland. In Section 3, we model the labor reallocation as a response to the changing demand structure. The reallocation has two parts: the exogenous increases in the share of new workers with business education and the endogenous movement of workers with technical education and experience to business occupations. We calibrate the model based on Czech and Polish data, and measure the discounted sum of output loss due to the imbalance in human capital. This amounts to 20 to 40 percent of the 1990 GDP.

Our paper can be viewed as a study of mismatch between the existing worker characteristics and those that the market demands. A much-studied mismatch of this nature is the excessive qualification of workers for available jobs, that is, overeducation (see AlbaRamirez 1993 for example). Another is the insufficient capacity of workers in adopting new technology, that is, skill-biased technological change (see Acemoglu and Zilibotti 2001 among others). These issues are more about the level mismatch than about the composition mismatch, that we focus on. Our paper also relates to other studies of educational changes and labor mobility in transition economies. Sarychev (1999) studies the changes from specialized vocational training to general training during the early period of transition in East Germany. Sorm and Terrell (2000) find a significant movement of labor into the finance, trade, and tourism sectors and out of the agricultural and industrial sectors in the Czech Republic. Similarly, Sabirianova (2002) finds the expansion of service and business occupations in Russia. In comparison, our paper highlights the changes from technical to business-related education/occupation. Also, we assess their quantitative significance based on an aggregate model. 


\section{Data Analysis}

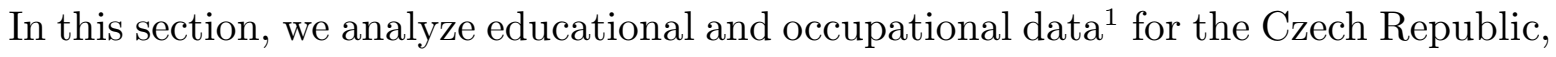
Hungary, and Poland since the early 1990s. The objective is to describe the reallocation of labor from the technical to the business fields. Table 1 presents the distribution of new graduates across fields. ${ }^{2}$ We can see a large shift away from the technical field in all three countries. In the Czech Republic and Poland, nearly all the shift was toward the business field with only a slight increase in the share of the other fields. In Hungary, the shift was all toward the other fields with no noticeable change in the business share. Figure 1 plots the ratio of the business share and the sum of business and technical shares (i.e., business share/[business share + technical share]), which illuminates the relative shift from the technical to the business fields.

Table 2 presents the distribution of workers across occupations. In the Czech Republic and Poland, over the whole period we can see a shift from technical to business occupations with little change in the other occupations, much like the shift in education. However, the pace of shift is uneven over the years, and even in the opposite direction in some years. In Hungary, we do not see the shift from technical to business occupations. If anything, the shift is from business to other occupations. Figure 2 plots the ratio of the business share and the sum of business and technical shares, illustrating the relative shift from the technical to the business occupations.

Table 3 presents occupational distribution in three other European countries, Austria, Germany, and Spain, for comparison. Austria and Germany, two other Central European countries, are a useful gauge for assessing the economic future of the Czech Republic, Hungary, and Poland. Spain went through its own economic transition after joining the EU in 1986, some twenty years ahead of the three countries of our inquiry, and provides

\footnotetext{
1 See the Appendix for the sources and the processing of the data.

2 We cautiously present the 1999-2001 data for the Czech Republic. Note the large decline in the total number of graduates for these years, which would be temporary. We should not infer a medium-term or long-term trend from these transitory years.
} 
an additional point of comparison. The table shows no pattern of change common to all three countries. In Austria, we can notice a shift from technical to business occupations, as in the Czech Republic and Poland, but on a smaller scale. In Germany, the shift is from technical to other occupations. ${ }^{3}$ In Spain the main shift is from business to other occupations. Figure 3 plots the ratio of the business share and the sum of business and technical shares. Although the patterns of change are dissimilar among the countries, the relative business share is uniformly higher than in the Czech Republic and Poland in the early years of the period. Thus the shift from business to technical occupations in the Czech Republic and Poland can be viewed as a sort of catching up with the other European countries.

In summary, our analysis shows that in the Czech Republic and Poland, there was a major reallocation of labor from technical to business education/occupation in the last decade. This is not a general pattern in European countries. Notably, in the Czech Republic and Poland the business share of occupation was lower than in all the other countries including Hungary, in the early 1990s. Based on this, we interpret Czech and Polish labor reallocation as a natural aspect of transition toward a market economy. Hungary began its market-based reform in the 1980s, earlier than the Czech Republic and Poland, which probably explains its relatively high business share in the early 1990 s. $^{4}$

\footnotetext{
3 The German data cover the entire country. The former East German part alone may have exhibited the same pattern of change as the Czech Republic and Poland.

4 Perhaps for this reason, Hungary received, as a share of GDP, much larger sums of foreign direct investment in the early and the mid-1990s than the Czech Republic or Poland did. To the extent that the foreign investment went to sectors that require few business skills, it would help explain why Hungary took a path dissimilar to the Czech and Polish one. From the late 1990s, the Czech Republic and Poland also received large foreign direct investments, which may have influenced their pattern of labor mobility. A more general point is that the long-run composition of human capital may be affected by the initial condition for any country, a counter point to the convergence hypothesis hinted at above.
} 


\section{Quantitative Exercise}

In this section, we conduct an exercise in order to quantitatively assess the significance of the gap between the technically-oriented workforce and the business-oriented labor demand during the transition paths of the Czech Republic and Poland, ${ }^{5}$ as documented in Section 2. The transition is modeled as follows. The economy is assumed to be on a balanced growth path for $t \leq 0$. There is an unexpected change in the demand structure (i.e., the parameter of the business/technical occupation share in the production function) starting at $t=1$. Labor reallocates from the technical to the business occupation following the change in demand structure. The reallocation has two parts. First, the share of new workers with a business education increases exogenously over time. Second, some workers, old and new, choose to work in the high-paying business occupation despite technical education and experience. Based on the calibrated model, we quantify the labor reallocation and the output loss due to the imbalance in human capital.

\subsection{The Worker's Decision Problem}

A worker receives either a business or a technical education before beginning his work life. Let the type of education be denoted by $s=1,2$, where $s=1$ means business education and $s=2$ means technical education. The type of education a worker receives is exogenous: he takes it as given in his decision problem. A worker's work life is 10 periods. This implies that the length of a period is 4 years under the assumption that a worker's work life is 40 years. ${ }^{6}$ Let the period of a worker's work life be denoted by $j=1,2, \ldots, 10$. Let the occupations denoted by $i=1,2$, where $i=1$ means business occupation and $i=2$ means technical occupation. In any period of his work life, a worker can work in either

\footnotetext{
5 That is, we conduct the exercise based on the Czech and Polish data. However, under the assumption that the Hungarian transition of the 1980s was similar to that of the Czech Republic and Poland in the 1990s, the results may also be relevant to the earlier transition in Hungary.

6 Since workers can choose their occupation in each period, the length of a period should be interpreted as the time it takes on average for a worker to have a new opportunity to move between technical and business occupations. The four-year length does not seem unreasonable.
} 
occupation. Let a worker's experience in an occupation, i.e., the number of periods he spent in the occupation, be denoted by $e=1,2, \ldots, 9$.

The effective labor input of a worker depends on the education he has received, the occupation in which he works, and his experience in that occupation. Let $a(s, i, e)$ denote the effective labor input by a worker who has received type $s$ education, works in occupation $i$, and has spent $e$ number of periods working in occupation $i$. We assume:

$$
\begin{array}{ll}
\log a(s, i, e)=\sigma_{1} e-\sigma_{2} e^{2} & \text { for } s=i \text { and } \\
a(s, i, e)=\lambda a(s, s, e) & \text { for } s \neq i,
\end{array}
$$

where $\sigma_{1}, \sigma_{2}>0$ and $0<\lambda<1$. The first equation is Mincerian, as commonly used in the labor literature. It captures the increasing and concave wage profile over experience. The parameter $\lambda$ captures the effective labor input of a worker who works in an occupation for which he is not educated. The wage of a worker is given by

$$
w_{t}(s, i, e)=\tilde{w}_{t}(i) a(s, i, e) .
$$

where $\tilde{w}_{t}(i)$ is the wage rate for one unit of effective labor input in occupation $i$.

Let $g_{t}(s, j)$ denote the date $t$ occupation of a worker who has received type $s$ education and is in the $j$ th period of his work life. The career path of a worker who has received type $s$ education and enters the work force in period $t$ is then $\left\{g_{t+j-1}(s, j)\right\}_{j}$. Given $\left\{g_{t+j-1}(s, j)\right\}_{j}$, the worker's experience path $\left\{e_{t+j-1}(s, j)\right\}_{j}$ is given by

$$
e_{t+j-1}(s, j)=\sum_{k=1}^{j-1} \eta\left(g_{t+j-1}(s, j), g_{t+k-1}(s, k)\right)
$$

where $\eta$ is an indicator function: $\eta\left(i, i^{\prime}\right)$ is equal to 1 if $i=i^{\prime}$, and equal to 0 otherwise. A worker's utility is the discounted linear sum of wages over his work life: the utility of a worker who has received type $s$ education and enters the work force in period $t$ is

$$
\sum_{k=1}^{10} \beta^{k-1} \tilde{w}_{t+k-1}\left(g_{t+k-1}(s, k)\right) a\left(s, g_{t+k-1}(s, k), e_{t+k-1}(s, k)\right)
$$


where the discount rate $\beta<1$. A worker's decision problem is to maximize his utility by choosing his career path, taking as given his education type $s$ and wage rates $\left\{\tilde{w}_{t}(i)\right\}$. The solution to this problem may not be unique: multiple career paths may maximize the worker's utility. Let $G_{t}(s)$ denote the set of utility-maximizing career paths for a worker entering the work force in period $t$ with education type $s$ :

$$
G_{t}(s)=\left\{\left\{g_{t+j}(s, j)\right\}_{j}:\left\{g_{t+j}(s, j)\right\}_{j} \text { maximizes the utility of the worker }\right\}
$$

This completes the description of the worker's decision problem.

\subsection{The Labor Supply}

We assume no population growth and normalize the number of workers who enter the work force to be one. Thus at any date there are 10 people in the work force, each person representing a different age group. Let $m_{t}(s)$ denote the number of workers who begin work life in period $t$ with education type $s: m_{t}(1)+m_{t}(2)=1$. Recall from the previous subsection that multiple career paths may maximize the utility of the worker. Thus in equilibrium workers of the same cohort with the same education may choose different career paths. Let $\mu_{t}\left(\left\{g_{t+j}(s, j)\right\}_{j}\right)$ denote the fraction of workers who choose the career $\left\{g_{t+j}(s, j)\right\}_{j}:$

$$
\sum_{G_{t}(s)} \mu_{t}\left(\left\{g_{t+j}(s, j)\right\}_{j}\right)=1
$$

Let $n_{t}(i)$ denote the number of workers in occupation $i$ in period $t$. Given the wage rates $\left\{\tilde{w}_{t}(i)\right\}$, the labor supply $\left\{n_{t}(i)\right\}$ is determined by the distribution of career paths $\left\{\mu\left(\left\{g_{t}(s, j)\right\}_{j}\right)\right\}$ that workers choose:

$$
n_{t}(i)=\sum_{\tau=t-9}^{t} \sum_{s} \sum_{G_{\tau}(s)} \eta\left(i, g_{t}(s, t-\tau+1)\right) \mu_{\tau}\left(\left\{g_{\tau+j}(s, j)\right\}_{j}\right) m_{\tau}(s)
$$


The workers working in an occupation in a period will differ in terms of their effective labor input due to differences in their education and experience. Let $\tilde{n}_{t}(i)$ denote the total effective labor input in occupation $i$ in period $t$ :

$$
\tilde{n}_{t}(i)=\sum_{\tau=t-9}^{t} \sum_{s} \sum_{G_{\tau}(s)} \eta\left(i, g_{t}(s, t-\tau+1)\right) a\left(s, i, e_{t}(s, t-\tau+1)\right) \mu_{\tau}\left(\left\{g_{\tau+j}(s, j)\right\}_{j}\right) m_{\tau}(s)
$$

where the experience $e_{t}(s, t-\tau+1)$ is determined by (3) given the career path $\left\{g_{\tau+j}(s, j)\right\}_{j}$. Again, the labor supply $\left\{n_{t}(i)\right\}$ and the effective labor supply $\left\{\tilde{n}_{t}(i)\right\}$ may not be unique since the utility-maximizing career path of workers of the same cohort and with the same education may not be unique.

\subsection{The Aggregate Economy}

The aggregate economy is a standard neoclassical one except for the following two features. First, labor input is differentiated by occupation. Second, we abstract from capital accumulation and the firm's profit-maximization problem. We simply assume that there is an aggregate production function and that the wage rates are determined by the marginal products of the labor inputs. The aggregate production function is

$$
Y_{t}=A_{t}\left[\tilde{n}_{t}(1)^{\alpha_{0}} \tilde{n}_{t}(2)^{1-\alpha_{0}}\right]^{2 / 3}
$$

for $t \leq 0$,

$$
Y_{t}=A_{t}\left[\tilde{n}_{t}(1)^{\alpha_{t}} \tilde{n}_{t}(2)^{1-\alpha_{t}}\right]^{2 / 3}
$$

for $t \geq 1$, and

$$
\frac{\alpha_{t+1}-\alpha_{t}}{\alpha_{\infty}-\alpha_{t}}=\rho
$$

where $0<\alpha_{0}, \alpha_{\infty}<1$ and $0<\rho<1 .^{7}$ The parameter $\alpha_{0}$ captures the relative demand for the two occupations before transition. The relative demand changes during transition: $\alpha_{t}$ increases in $t$. The parameter $\alpha_{\infty}$ captures the relative demand in the long run and

\footnotetext{
7 The exponent $2 / 3$ would be the labor income share in a Cobb-Douglas function with capital and labor inputs, as commonly used in macro models.
} 
the parameter $\rho$ captures the speed of change in demand, a higher value meaning a faster change. We set $\alpha_{0}=m_{0}(1)$ for all $t \leq 0$, and $\alpha_{\infty}=m_{\infty}(1)$. This specification insures that before transition the composition of new workers each period exactly met the old demand structure, and will exactly meet the new demand structure in the long run. We assume the sequence of productivity $\left\{A_{t}\right\}$ to have followed some constant annual growth path for $t \leq 0$. This pre-transition growth rate of productivity is not essential for the exercise and does not need to be specified. We assume the sequence of productivity to follow a new constant annual growth path after the transition starts: for $t \geq 1$

$$
A_{t+1}=A_{t}^{1+\gamma}
$$

The wage rates are given by $\tilde{w}_{t}(i)=\partial Y_{t} / \partial \tilde{n}_{t}(i)$. The equilibrium of the economy is the distribution of career paths $\left\{\mu\left(\left\{g_{t}(s, j)\right\}_{j}\right)\right\}$, the labor supply $\left\{n_{t}(i)\right\}$, the effective labor

supply $\left\{\tilde{n}_{t}(i)\right\}$, and the wage rates $\left\{\tilde{w}_{t}(i)\right\}$ such that the distribution of career paths is derived from the workers' utility maximization problem given the wage rates; the labor supply and the effective labor supply are derived from the distribution of career paths; and the wage rates are derived from the effective labor supply.

\subsection{Calibration}

For the exercise, we need to specify the discount rate $\beta$, the productivity growth rate $\gamma$, the education premium parameter $\lambda$, the experience premium parameters $\sigma_{1}$ and $\sigma_{2}$, the educational distribution of new workers $\left\{m_{t}(s)\right\}$, and the speed of demand change $\rho$. We set $\beta=.85$. This implies a real annual interest rate of about $4 \%$ under constant consumption over periods. We set $\gamma=.082$, which implies an annual growth rate of about $2 \%$. We set $\sigma_{1}$ to be in the range of .05 to .15 , and $\sigma_{2}$ in the range of .0033 to .01. Recall that the length of a period is four years. At an annual rate, these ranges are equivalent to .012 to .036 , and .0002 to .0006 , respectively. The low end of the ranges corresponds to 
the values for the transition economies in the early 1990s; the high end corresponds to the values for Western European countries. $^{8}$

We set the initial and the long-run business shares of education/occupation (i.e., $m_{0}(1)$ and $m_{\infty}(1)$ or, equivalently, $\alpha_{0}$ and $\left.\alpha_{\infty}\right)$ based on our data analysis in Section 2. We use the composition of workers with business or technical education/occupations, and ignore the other workers. Figure 1 suggests $m_{0}(1)$ to be about .25 and $m_{\infty}(1)$ to be somewhere above .50 for both the Czech Republic and Poland. To better guess at $m_{\infty}(1)$, we calculated the business share of education in the 1990s for Austria in the same way as we did for the Czech Republic, Poland, and Hungary. ${ }^{9}$ We found that the business share was stable at about $57 \%$. Therefore, one reasonable set of values for $m_{0}(1)$ and $m_{\infty}(1)$ are .25 and .55 , respectively. On the other hand, Figure 2 suggests quite different values. A rough guess based on this figure would set $m_{0}(1)$ and $m_{\infty}(1)$ at .20 and .35 for the Czech Republic, and at .30 and .45 for Poland. We conducted the exercise for all three sets of values: $\left(m_{0}(1), m_{\infty}(1)\right)$ equal to $(.25, .55),(.20, .35)$, and $(.30, .45) .{ }^{10}$ Given $\left(m_{0}(1), m_{\infty}(1)\right)$, Figure 1 suggests a linear path of adjustment in educational composition for the first three periods: $m_{t}(1)=t\left(m_{\infty}(1)-m_{0}(1)\right) / 3$ for $t=1,2$ and $m_{t}(1)=m_{\infty}(1)$ for $t \geq 3$. The solid line draws the adjustment path for the case of $\left(m_{0}(1), m_{\infty}(1)\right)=(.25, .55)$.

The parameters that remain to be chosen are $\lambda$ and $\rho$. These parameters are difficult to relate to the data directly. Instead we chose the values of these two parameters so that the endogenous variables under the chosen values match the data along some dimensions.

8 Bird et al. (1994), Krueger and Pischke (1995), and Chase(1998) document the low experience premium in transition economies in the early 1990s. One caveat is that these studies report a pooledexperience premium while the relevant premium for our exercise is an occupation-specific one. The former is smaller than the latter since some workers switch occupation and lose (some) premium. If workers in transition economies switched occupation more than workers in Western Europe in the early 1990s, this would account for some of the observed premium differential between them.

9 See the Appendix for the details.

10 That we have rough and diverse ranges is not surprising. We have only limited data for the early 1990s and the long-run business share is difficult to predict. More basically, the way we classified the education types and occupations is inevitably arbitrary. Trying diverse ranges is a sensible strategy given this situation. 
Specifically, we chose to match the size of labor reallocation and the cross-occupational wage differential at date two, which corresponds to year 1998. From Figure 2, assuming the initial and the long-run business shares of $(.20, .35)$ for the Czech Republic and $(.30, .45)$ for Poland, the size of labor reallocation during the first two periods is about $80 \%$ of the total for the former and about $53 \%$ of the total for the latter. We chose the model to replicate these percentages of reallocation. As for the wage differential, the Czech Labor Force Survey does not contain information about wages. However, we were able to find that information in the Microsensus conducted in 1992 and 1996. Conducting the same data analysis as for the Labor Force Survey, we found that wages in business occupations grew $4 \%$ more than the average and wages in technical occupations grew $9 \%$ less than the average. ${ }^{11}$ The Polish Labor Force Survey contains wage information, but only from 1995. We found that during the 1995-1999 period, wages in business occupations grew $4 \%$ more than the average and wages in technical occupations grew $7 \%$ less than the average. ${ }^{12}$ Based on this information, for both countries we chose the model to generate a $25 \%$ wage differential between the business and the technical occupations at date 2, starting from zero differential at date 0 .

The algorithm for finding the equilibrium under a given set of parameter values is as follows. First, we set the labor supply for $t \geq 1$ to be such that every worker works in the occupation for which he is educated, i.e., workers with a business education work in the business occupation and workers with a technical education work in the technical occupation. Second, we calculate the wage rates for $t \geq 1$ under this labor supply. Third, we solve the career-decision problems of individual workers under these wage rates and

\footnotetext{
11 For 1996, when the Microsensus and the Labor Force Survey data sets can be directly compared, the business share of workers in the Microsensus is two or three percentages higher than in the Labor Force Survey, while the technical share is almost the same. Our overall impression is that the two data sets are comparable and the discrepancy reflects the small sample size for the Microsensus, which was about three thousand for 1992 and about five thousand for 1996 .

12 This pattern of wage-growth differential in both countries corroborates our modeling choice for labor mobility: the change in demand structure creates the wage differential, which leads to supply response. We chose not to present the wage data systematically due to their limited coverage.
} 
derive a new labor supply for $t \geq 1$. Fourth, we update the original labor supply by a small amount so that it is closer to the new labor supply. This marginal update rule avoids the non-converging oscillation of labor supply as the update is repeated. Fifth, we recalculate the wage rates for $t \geq 1$ under this updated labor supply. Sixth, we repeat the third, the fourth, and the fifth steps until the labor supply and the wage rates converge. By construction, the limit of the convergence is the equilibrium.

We calculated equilibria using various values of $\lambda$ and $\rho$, and found the pattern that for a higher $\lambda$ or for a higher $\rho$, there is more labor reallocation. Intuitively, a higher $\lambda$ (i.e., a lower occupation-specific experience premium) makes people more willing to move, and a higher $\rho$ (i.e., a higher speed of demand change) creates more of a wage premium for the business occupation, attracting more movers. Thus each value of $\lambda$ is mapped to a unique value of $\rho$ so that a given size of reallocation is maintained. We also found that as we increase $\lambda$, at the same time decreasing $\rho$ according to the mapping, the wage differential decreases. In fact, we can deduce this pattern as a property of the model: given the Cobb-Douglas production function, a lower $\rho$ implies a lower business share of aggregate wage bill, and under a fixed business share of occupations this leads to a lower average wage of the business occupation relative to that of the technical occupation. Thus there is a unique set of values of $\lambda$ and $\rho$ that generate a given set of the reallocation size and the wage differential at date 2 .

\subsection{Results}

Table 4 summarizes the results. Each row contains a set of parameter values and a description of the model economy under those values. Our interest is the labor reallocation from the technical to the business occupation, which is determined by demand and supply factors in the labor market. The demand factors are the total change in demand, $\alpha_{\infty}-\alpha_{0}$, and the speed of its change, $\rho$. These two factors work as substitutes for each other in 
determining the change in demand in the early periods. The supply factors are the educational premium, $1 / \lambda$, and the occupation-specific experienced premium, $\sigma_{1}$ (and $\sigma_{2}$ which is scaled accordingly). These two factors work as substitutes for each other in determining the supply response, i.e., the movement of workers into the business occupation despite technical education and experience, aside from the exogenous increase in the share of new workers with a business education. For these workers, call them movers, the advantage of high wages in the business occupation outweighs the disadvantages of improper education and lack of experience. ${ }^{13}$ The wage differential between the business and the technical occupations reflects the relative strengths of demand and supply factors. ${ }^{14}$

The main difference between the Czech Republic and Poland is the observed speed of labor reallocation (i.e., the date-two completion rates of $80 \%$ versus $53 \%$ ). For the Czech Republic we were barely able to simulate its high speed of reallocation, in some cases reaching the corners in the demand-pull and the supply-push factors (e.g., $\rho=1$, $\lambda=1)$. For Poland the speed is more moderate and so are the required demand and supply factors. For both countries, there is a sizeable movement from the technical to the business occupation, all concentrated in the first period or two. The share of movers among all workers is of the order of 10 to 20 percent in the early periods. The business occupation continues to expand as a larger share of new workers are educated in business

13 The movers are concentrated in young age groups. Younger workers have less experience, so their loss of effective labor input from working in the business occupation is lower. Further, younger workers have more remaining work life to accumulate experience in the business occupation. On the other hand, since the wage premium of the business occupation is temporary, older workers can take advantage of this premium by moving into the business occupation for a greater fraction of their remaining work life than younger workers. Under the parameter values chosen for the exercise, the experience factor largely outweighs the temporary-premium factor. This result is consistent with the empirical findings in Sorm and Terrell (2000).

14 The movers enjoy the wage premium in business occupations, but their wage is still lower than that of their fellow workers with business education and experience. Thus labor mobility lowers the average wage rate in the business occupation (i.e., the total wage bill divided by the number of workers in the business occupation), and the average wage differential between the business and the technical occupations is less than the effective wage differential between the two occupations. 
than in the past. By the logic of the life cycle, it takes about one generation for the economy to complete the labor reallocation and reach a balanced growth path.

We can quantify the welfare effect of the imbalance in human capital as follows. We can calculate the aggregate output path given a set of model parameter values. Call this the actual path. We can also calculate a hypothetical output path under the same values except that at each date and for each age group, the business-technical composition of workers' education and experience is assumed to (magically) match the business-technical composition of demand. By construction, the actual path lies below the hypothetical path during the period of adjustment. We can calculate the discounted sum of output gap between the actual and the hypothetical paths. For both countries, this sum is of the order of 5 to 10 percent of date zero output, largely depending on the total size of demand change. Since the length of a period is four years, this is equivalent to 20 to 40 percent of the 1990 GDP. ${ }^{15}$

\section{Conclusion}

In this paper, we studied the changing composition of human capital in the Czech Republic, Hungary, and Poland since 1990. For the Czech Republic and Poland, we documented the reallocation of labor from technical to business education/occupations, starting from a low business share in comparison to Western European countries. We interpret this change as an adjustment necessary for their transition to a market economy. We did not find the same pattern in Hungary, which seems to reflect that it started its transition in the 1980s, earlier than the other two countries. We constructed a model where labor reallocates as a response to the changing demand structure. When calibrated for the Czech Republic and Poland, the model generates a large movement of workers with technical education and experience into business occupations in the early 1990s, and a more gradual

\footnotetext{
15 To put this range in perspective, consider that Lucas (1987) estimated the welfare effect of business cycles in the US to be equivalent to perpetually losing about one half percent of consumption, which translates to less than $15 \%$ of a single year's GDP.
} 
inflow of new workers with a business education. The discounted sum of output loss due to the imbalance in human capital amounts to 20 to 40 percent of the 1990 GDP.

We note some shortcomings of our exercise. First, by focusing on labor reallocation we have abstracted from the compositional changes of human capital within an education type or within an occupation. As mentioned, our exercise is about a readily quantifiable portion of the changes, so it understates their quantitative significance. Second, we have little to say about what determine the changes in the demand structure except for the notion of their necessity in the transition to a market economy. One can conjecture that the technically skewed stock of human capital may induce a degree of specialization in technically-oriented production in the Czech Republic and Poland vis-a-vis European countries (see footnote 4). Third, we have not addressed the issues of optimal policy. We can only note the dramatic changes in the educational system in all three countries, which indicates that educational policy has been responsive to changes in the demand structure. 
Appendix

A. Construction of Table 1 and Figure 1 (and the Exercise for Austria)

To construct Table 1, we consulted the Statistical Yearbooks of the Czech Republic, Hungary, and Poland. In the Yearbooks, new graduates are classified by the types of school and by the fields within each type of school. The types of school can be broadly reclassified into vocational school, grammar school, and university. We excluded new graduates of grammar school, who mostly advance to university, since our exercise is about new entrants to the labor market. We pooled new graduates across school types and fields into business fields, technical fields, and other fields. For calibration of the model, we conducted the same exercise for Austria for years 1993 and 1998. We consulted the Austrian Statistics on Universities in addition to the Austrian Statistical Yearbook for these two years. The details of the pooling are as follows:

\section{Czech Republic}

Business fields in vocational schools: business and services. Business fields in universities: economics and business. Technical fields in vocational schools: machine control and operation + mechanical engineering and metallurgy + electrical engineering, transport and communications + chemistry and food industry + construction + fashion and clothing + textile and garment industry + wood processing and shoe industry. Technical fields in universities: mining + metallurgy + mechanical engineering + electrical engineering + industrial chemistry + food + architecture + construction + footwear industry + wood and paper production + transport. Other fields in vocational schools: agriculture and forestry + veterinary medicine + arts and handicraft + librarians and journalists + arts + philosophy and theology + health services + physical training and sports + public and legal administration + environmental protection + pedagogy. Other fields in universities: agriculture, forestry, and veterinary medicine + philosophy + politics + history + journalism + philology + psychology + sciences of arts + medicine and pharmacy + physical training + law + physics and mathematics + geology + geography + chemistry + biology + ecology and environmental protection + pedagogy + teacher training.

\section{Hungary}

Business fields in vocational schools: economics + commerce + trade + catering + miscellaneous service industries. Business fields in universities: economics and business. Technical 
fields in vocational schools: mining + metallurgy + other iron and metal industry + engineering + electrical engineering and energy industry + precision engineering + chemical industry + paper industry + food processing industry + building material industry + construction + transport, post, telecommunications + textile industry + leather, fur and

shoe industry + clothing industry + wood industry + printing industry. Technical fields in universities: engineering. Other fields in vocational schools: plant cultivation + animal husbandry + art + sanitary education + kindergarten teachers. Other fields in universities: agricultural + veterinary + liberal arts + fine arts + theology + medical science + sanitary + physical education + law and state administration + natural science + teacher training (higher grade) + teacher training (higher grade) for disabled children + teacher training (lower grade) + kindergarten teacher.

\section{$\underline{\text { Poland }}$}

Business fields in vocational schools: commerce and business + services. Business fields in universities: commercial and business administration + services. Technical fields in vocational schools: trade, craft, and industrial programs + transport and communications. Technical fields in universities: engineering + architecture and town planning + transport and communications. Other fields in vocational schools: agriculture, forestry and fishery + fine and applied arts + health-related auxiliaries + teacher training. Other fields in universities: agriculture, forestry and fishery + fine and applied arts + humanities + religion and theology + social and behavioral science + home economics + mass communication and documentation + medical science + law + natural science + mathematics and computer science + education science and teacher training.

\section{$\underline{\text { Austria }}$}

Business fields in vocational schools: commerce + office and administrative work + data processing + hotel management, catering and tourism. Business fields in universities: social, economic, and business studies excluding sociology. Technical fields in vocational schools: industry and trade + fashion and clothing. Technical fields in universities: technical sciences + metallurgy. Other fields in vocational schools: agriculture and forestry + animal nursing + domestic science + social work + arts + craft + nursing + medical service + teaching. Other fields in universities: agriculture + veterinary + social sciences + theology + arts + social work + medicine + medical service + law + military + natural sciences + teaching. 


\section{B. Construction of Table 2, Figure 2, Table 3, and Figure 3}

To construct Tables 2 and 3, we consulted the Labor Force Surveys of the respective countries. For the Czech Republic, Hungary, and Poland, we obtained the data directly from the respective national statistical offices. For Austria, Germany, and Spain, we obtained the data from Eurostat, the statistical office of the European Union. The Czech Republic and Poland have conducted their Labor Force Surveys based on the ISCO-88 (International Standard Classification of Occupations) since 1993 and 1994, respectively. Hungary has conducted the Labor Force Surveys based on its own classification system titled HSCO-93 (Hungarian Standard Classification of Occupations) since 1993, but the Statistical Office provides instruction on how to convert HSCO-93 to ISCO-88. We grouped the two-digit ISCO-88 occupation codes into business occupations, technical occupations, and other occupations. The tables present the results for the fourth quarter of each year for the Czech Republic, Hungary, and Poland; the first quarter for Austria; and the second quarter for Germany and Spain. The figures present the results for all quarters for which we could obtain data. The details of the grouping of occupation codes are as follows:

Business Occupations: corporate managers $(12)+$ managers of small enterprises $(13)+$ office clerks (41) + customer service clerks (42) + models, salespersons, and demonstrators (52). Technical Occupations: physical, mathematical and engineering science professionals $(21)+$ physical and engineering science associate professionals $(31)+$ extraction and building trade workers $(71)+$ metal, machinery, and related trade workers $(72)+$ precision, handicraft, craft printing, and related trade workers $(73)+$ other craft and related trade workers $(74)+$ stationary-plant and related operators $(81)+$ machine operators and assemblers $(82)+$ drivers and mobile plant operators (83). Other Occupations: legislators, senior officials, and managers (11) + life science and health professionals $(22)+$ teaching professionals $(23)+$ other professionals $(24)+$ life science and health associate professionals $(32)+$ teaching associate professionals $(33)+$ other associate professionals (34) + personal and protective services workers $(51)+$ skilled agricultural and fishery workers $(61)+$ subsistence agricultural and fishery workers $(62)+$ sales and service elementary occupations (91) + agricultural, fishery and related laborers (92) + laborers in mining, construction, manufacturing and transport (93). 


\section{References}

Acemoglu, D. and Zilibotti, F. (2001), "Productivity Differences," Quarterly Journal of Economics 116:563-606.

Alba-Ramirez, A. (1993), "Mismatch in the Spanish Labor Market: Overeducation?," Journal of Human Resources 28(2):259-78.

Barro, R. and Lee, J. (1996), "International Measures of Schooling Years and Schooling Quality," American Economic Review 86:218-23.

Bird, E., Schwarze, J., and Wagner, G. (1994), "Wage Effects of the Move toward Free Markets in East Germany," Industrial and Labor Relations Review 47:390-400.

Chase, R. (1998), "Markets for Communist Human Capital: Returns to Education and Experience in the Czech Republic and Slovakia," Industrial and Labor Relations Review 51:401-23.

Krueger, A. and Pischke, J. (1995), "A Comparative Analysis of East and West German Labor Markets: Before and After Unification," in Richard B. Freeman and Lawrence F. Katz (eds.), Differences and Changes in Wage Structures, University of Chicago Press.

Sabirianova, K. (2002), "The Great Human Capital Reallocation: An Empirical Analysis of Occupational Mobility in Transitional Russia," Journal of Comparative Economics 30:191-217.

Sarychev, A. (1999), "Dynamic Skills Acquisition Choice - Jacks of All Trades vs. Dab Hands," Manuscript, Economics Department, Massachusetts Institute of Technology.

Sorm, V. and Terrell, K. (2000), "Sectoral Restructuring and Labor Mobility: A Comparative Look at the Czech Republic," Journal of Comparative Economics 28:431-55. 
Table 1: Distribution of New Graduates across Fields

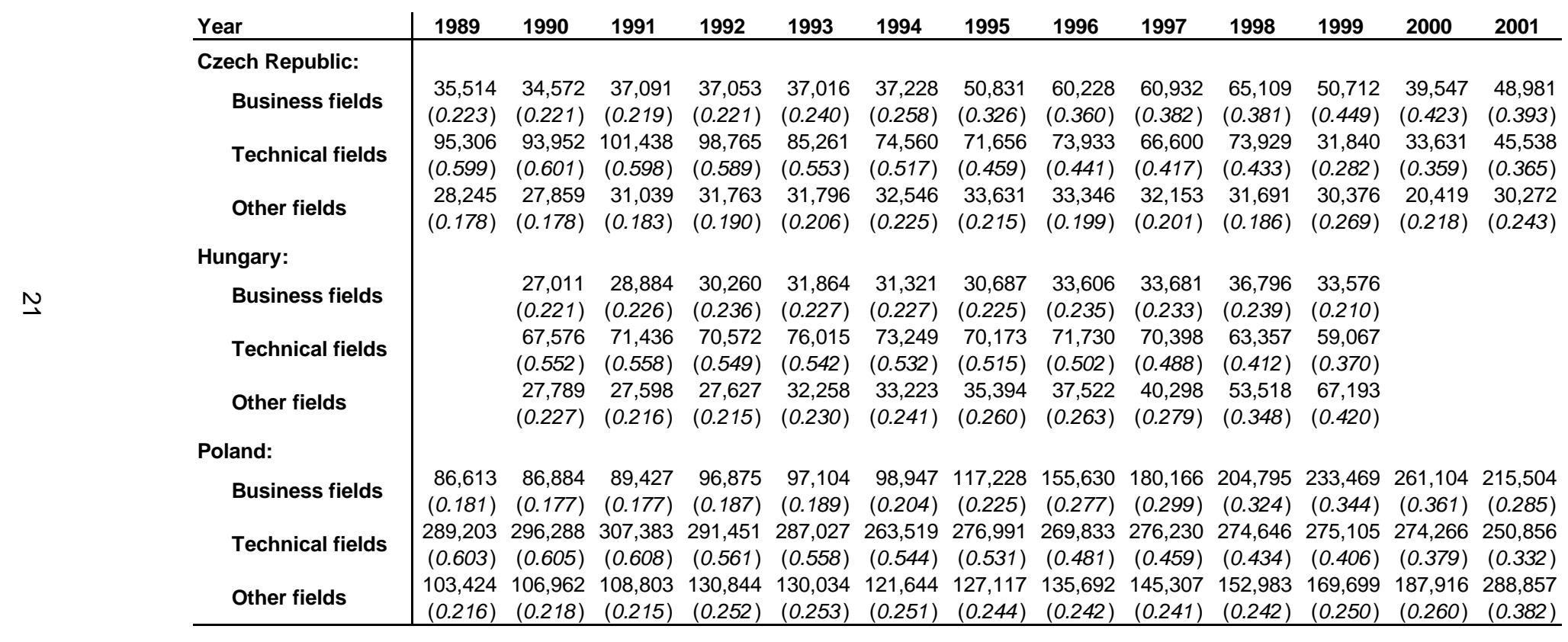

Note: See Appendix for sources. 
Table 2: Distribution of Workers across Occupations

\begin{tabular}{|c|c|c|c|c|c|c|c|c|c|c|}
\hline Year & 1993 & 1994 & 1995 & 1996 & 1997 & 1998 & 1999 & 2000 & 2001 & 2002 \\
\hline \multicolumn{11}{|l|}{ Czech Republic: } \\
\hline Business occupations & $\begin{array}{r}839 \\
(0.170)\end{array}$ & $\begin{array}{r}931 \\
(0.189)\end{array}$ & $\begin{array}{r}967 \\
(0.193)\end{array}$ & $\begin{array}{r}998 \\
(0.200)\end{array}$ & $\begin{array}{r}999 \\
(0.202)\end{array}$ & $\begin{array}{r}983 \\
(0.203)\end{array}$ & $\begin{array}{r}922 \\
(0.194)\end{array}$ & $\begin{array}{r}926 \\
(0.195)\end{array}$ & $\begin{array}{r}948 \\
(0.200)\end{array}$ & $\begin{array}{r}982 \\
(0.204)\end{array}$ \\
\hline Technical occupations & $\begin{array}{r}2,164 \\
(0.439)\end{array}$ & $\begin{array}{r}2,155 \\
(0.437)\end{array}$ & $\begin{array}{r}2,092 \\
(0.419)\end{array}$ & $\begin{array}{r}2,084 \\
(0.418)\end{array}$ & $\begin{array}{r}2,038 \\
(0.412)\end{array}$ & $\begin{array}{r}2,005 \\
(0.413)\end{array}$ & $\begin{array}{r}1,971 \\
(0.414)\end{array}$ & $\begin{array}{r}1,956 \\
(0.412)\end{array}$ & $\begin{array}{r}1,967 \\
(0.413)\end{array}$ & $\begin{array}{r}1,992 \\
(0.414)\end{array}$ \\
\hline Other occupations & $\begin{array}{r}1,923 \\
(0.391)\end{array}$ & $\begin{array}{r}1,849 \\
(0.374)\end{array}$ & $\begin{array}{r}1,939 \\
(0.388)\end{array}$ & $\begin{array}{r}1,906 \\
(0.382)\end{array}$ & $\begin{array}{r}1,904 \\
(0.386)\end{array}$ & $\begin{array}{r}1,862 \\
(0.384)\end{array}$ & $\begin{array}{r}1,870 \\
(0.392)\end{array}$ & $\begin{array}{r}1,867 \\
(0.393)\end{array}$ & $\begin{array}{r}1,846 \\
(0.387)\end{array}$ & $\begin{array}{r}1,844 \\
(0.382)\end{array}$ \\
\hline \multicolumn{11}{|l|}{ Hungary: } \\
\hline Business occupations & $\begin{array}{r}897 \\
(0.239)\end{array}$ & $\begin{array}{r}886 \\
(0.239)\end{array}$ & $\begin{array}{r}840 \\
(0.230)\end{array}$ & $\begin{array}{r}844 \\
(0.230)\end{array}$ & $\begin{array}{r}824 \\
(0.224)\end{array}$ & $\begin{array}{r}823 \\
(0.220)\end{array}$ & $\begin{array}{r}864 \\
(0.226)\end{array}$ & $\begin{array}{r}890 \\
(0.229)\end{array}$ & $\begin{array}{r}862 \\
(0.225)\end{array}$ & \\
\hline Technical occupations & $\begin{array}{r}1,466 \\
(0.390)\end{array}$ & $\begin{array}{r}1,425 \\
(0.385)\end{array}$ & $\begin{array}{r}1,406 \\
(0.384)\end{array}$ & $\begin{array}{r}1,386 \\
(0.378)\end{array}$ & $\begin{array}{r}1,416 \\
(0.386)\end{array}$ & $\begin{array}{r}1,448 \\
(0.386)\end{array}$ & $\begin{array}{r}1,474 \\
(0.386)\end{array}$ & $\begin{array}{r}1,482 \\
(0.382)\end{array}$ & $\begin{array}{r}1,490 \\
(0.389)\end{array}$ & \\
\hline Other occupations & $\begin{array}{r}1,391 \\
(0.371)\end{array}$ & $\begin{array}{r}1,393 \\
(0.376)\end{array}$ & $\begin{array}{r}1,413 \\
(0.386)\end{array}$ & $\begin{array}{r}1,440 \\
(0.392)\end{array}$ & $\begin{array}{r}1,431 \\
(0.390)\end{array}$ & $\begin{array}{r}1,475 \\
(0.394)\end{array}$ & $\begin{array}{r}1,484 \\
(0.388)\end{array}$ & $\begin{array}{r}1,506 \\
(0.388)\end{array}$ & $\begin{array}{r}1,482 \\
(0.387)\end{array}$ & \\
\hline \multicolumn{11}{|l|}{ Poland: } \\
\hline Business occupations & & $\begin{array}{r}2,732 \\
(0.186)\end{array}$ & $\begin{array}{r}2,868 \\
(0.195)\end{array}$ & $\begin{array}{r}2,974 \\
(0.198)\end{array}$ & $\begin{array}{r}3,147 \\
(0.206)\end{array}$ & $\begin{array}{r}3,188 \\
(0.209)\end{array}$ & $\begin{array}{r}3,001 \\
(0.207)\end{array}$ & $\begin{array}{r}3,028 \\
(0.209)\end{array}$ & $\begin{array}{r}2,910 \\
(0.208)\end{array}$ & $\begin{array}{r}2,803 \\
(0.205)\end{array}$ \\
\hline Technical occupations & & $\begin{array}{r}4,748 \\
(0.323)\end{array}$ & $\begin{array}{r}4,794 \\
(0.326)\end{array}$ & $\begin{array}{r}4,998 \\
(0.332)\end{array}$ & $\begin{array}{r}5,120 \\
(0.336)\end{array}$ & $\begin{array}{r}5,154 \\
(0.337)\end{array}$ & $\begin{array}{r}4,751 \\
(0.328)\end{array}$ & $\begin{array}{r}4,611 \\
(0.319)\end{array}$ & $\begin{array}{r}4,334 \\
(0.310)\end{array}$ & $\begin{array}{r}4,088 \\
(0.299)\end{array}$ \\
\hline Other occupations & & $\begin{array}{r}7,213 \\
(0.491)\end{array}$ & $\begin{array}{r}7,058 \\
(0.479)\end{array}$ & $\begin{array}{r}7,066 \\
(0.470)\end{array}$ & $\begin{array}{r}6,978 \\
(0.458)\end{array}$ & $\begin{array}{r}6,935 \\
(0.454)\end{array}$ & $\begin{array}{r}6,737 \\
(0.465)\end{array}$ & $\begin{array}{r}6,831 \\
(0.472)\end{array}$ & $\begin{array}{r}6,726 \\
(0.481)\end{array}$ & $\begin{array}{r}6,765 \\
(0.495)\end{array}$ \\
\hline
\end{tabular}

Note: All numbers are in thousands. See Appendix for sources. 
Table 3: Distribution of Workers across Occupations in Other European Countries

\begin{tabular}{|c|c|c|c|c|c|c|c|c|c|c|c|}
\hline Year & 1992 & 1993 & 1994 & 1995 & 1996 & 1997 & 1998 & 1999 & 2000 & 2001 & 2002 \\
\hline \multicolumn{12}{|l|}{ Austria: } \\
\hline Business occupations & & & & $\begin{array}{r}985 \\
(0.268)\end{array}$ & $\begin{array}{r}1,014 \\
(0.280)\end{array}$ & $\begin{array}{r}1,008 \\
(0.279)\end{array}$ & $\begin{array}{r}1,015 \\
(0.280)\end{array}$ & $\begin{array}{r}1,056 \\
(0.287)\end{array}$ & $\begin{array}{r}1,067 \\
(0.290)\end{array}$ & $\begin{array}{r}1,086 \\
(0.294)\end{array}$ & $\begin{array}{r}1,079 \\
(0.289)\end{array}$ \\
\hline Technical occupations & & & & $\begin{array}{r}1,243 \\
(0.338)\end{array}$ & $\begin{array}{r}1,133 \\
(0.313)\end{array}$ & $\begin{array}{r}1,120 \\
(0.310)\end{array}$ & $\begin{array}{r}1,134 \\
(0.313)\end{array}$ & $\begin{array}{r}1,148 \\
(0.312)\end{array}$ & $\begin{array}{r}1,145 \\
(0.311)\end{array}$ & $\begin{array}{r}1,134 \\
(0.307)\end{array}$ & $\begin{array}{r}1,138 \\
(0.305)\end{array}$ \\
\hline Other occupations & & & & $\begin{array}{r}1,447 \\
(0.394)\end{array}$ & $\begin{array}{r}1,470 \\
(0.406)\end{array}$ & $\begin{array}{r}1,481 \\
(0.410)\end{array}$ & $\begin{array}{r}1,477 \\
(0.407)\end{array}$ & $\begin{array}{r}1,474 \\
(0.401)\end{array}$ & $\begin{array}{r}1,472 \\
(0.400)\end{array}$ & $\begin{array}{r}1,477 \\
(0.399)\end{array}$ & $\begin{array}{r}1,517 \\
(0.406)\end{array}$ \\
\hline \multicolumn{12}{|l|}{ Germany: } \\
\hline Business occupations & $\begin{array}{r}8,318 \\
(0.239)\end{array}$ & $\begin{array}{r}8,424 \\
(0.241)\end{array}$ & $\begin{array}{r}8,450 \\
(0.243)\end{array}$ & $\begin{array}{r}8,435 \\
(0.242)\end{array}$ & $\begin{array}{r}8,242 \\
(0.235)\end{array}$ & $\begin{array}{r}8,205 \\
(0.236)\end{array}$ & $\begin{array}{r}8,139 \\
(0.233)\end{array}$ & $\begin{array}{r}8,320 \\
(0.234)\end{array}$ & $\begin{array}{r}8,354 \\
(0.233)\end{array}$ & $\begin{array}{r}8,436 \\
(0.234)\end{array}$ & $\begin{array}{r}8,356 \\
(0.234)\end{array}$ \\
\hline Technical occupations & $\begin{array}{r}12,995 \\
(0.373)\end{array}$ & $\begin{array}{r}12,557 \\
(0.359)\end{array}$ & $\begin{array}{r}12,270 \\
(0.353)\end{array}$ & $\begin{array}{r}12,236 \\
(0.351)\end{array}$ & $\begin{array}{r}12,421 \\
(0.353)\end{array}$ & $\begin{array}{r}12,066 \\
(0.347)\end{array}$ & $\begin{array}{r}12,122 \\
(0.346)\end{array}$ & $\begin{array}{r}12,156 \\
(0.341)\end{array}$ & $\begin{array}{r}12,161 \\
(0.339)\end{array}$ & $\begin{array}{r}12,099 \\
(0.336)\end{array}$ & $\begin{array}{r}11,803 \\
(0.330)\end{array}$ \\
\hline Other occupations & $\begin{array}{r}13,532 \\
(0.388)\end{array}$ & $\begin{array}{r}13,971 \\
(0.400)\end{array}$ & $\begin{array}{r}14,068 \\
(0.404)\end{array}$ & $\begin{array}{r}14,189 \\
(0.407)\end{array}$ & $\begin{array}{r}14,476 \\
(0.412)\end{array}$ & $\begin{array}{r}14,532 \\
(0.418)\end{array}$ & $\begin{array}{r}14,742 \\
(0.421)\end{array}$ & $\begin{array}{r}15,150 \\
(0.425)\end{array}$ & $\begin{array}{r}15,367 \\
(0.428)\end{array}$ & $\begin{array}{r}15,487 \\
(0.430)\end{array}$ & $\begin{array}{r}15,604 \\
(0.436)\end{array}$ \\
\hline \multicolumn{12}{|l|}{ Spain: } \\
\hline Business occupations & $\begin{array}{r}3,198 \\
(0.248)\end{array}$ & $\begin{array}{r}3,076 \\
(0.250)\end{array}$ & $\begin{array}{r}2,968 \\
(0.244)\end{array}$ & $\begin{array}{r}2,901 \\
(0.232)\end{array}$ & $\begin{array}{r}3,012 \\
(0.236)\end{array}$ & $\begin{array}{r}3,109 \\
(0.236)\end{array}$ & $\begin{array}{r}3,161 \\
(0.230)\end{array}$ & $\begin{array}{r}3,298 \\
(0.227)\end{array}$ & $\begin{array}{r}3,461 \\
(0.226)\end{array}$ & $\begin{array}{r}3,551 \\
(0.224)\end{array}$ & $\begin{array}{r}3,580 \\
(0.220)\end{array}$ \\
\hline Technical occupations & $\begin{array}{r}4,293 \\
(0.333)\end{array}$ & $\begin{array}{r}3,935 \\
(0.319)\end{array}$ & $\begin{array}{r}3,921 \\
(0.322)\end{array}$ & $\begin{array}{r}3,935 \\
(0.315)\end{array}$ & $\begin{array}{r}3,939 \\
(0.309)\end{array}$ & $\begin{array}{r}4,075 \\
(0.309)\end{array}$ & $\begin{array}{r}4,276 \\
(0.312)\end{array}$ & $\begin{array}{r}4,592 \\
(0.316)\end{array}$ & $\begin{array}{r}4,847 \\
(0.317)\end{array}$ & $\begin{array}{r}5,111 \\
(0.322)\end{array}$ & $\begin{array}{r}5,184 \\
(0.319)\end{array}$ \\
\hline Other occupations & $\begin{array}{r}5,402 \\
(0.419) \\
\end{array}$ & $\begin{array}{r}5,312 \\
(0.431) \\
\end{array}$ & $\begin{array}{r}5,297 \\
(0.435) \\
\end{array}$ & $\begin{array}{r}5,658 \\
(0.453) \\
\end{array}$ & $\begin{array}{r}5,810 \\
(0.455) \\
\end{array}$ & $\begin{array}{r}6,007 \\
(0.455) \\
\end{array}$ & $\begin{array}{r}6,282 \\
(0.458) \\
\end{array}$ & $\begin{array}{r}6,619 \\
(0.456) \\
\end{array}$ & $\begin{array}{r}6,998 \\
(0.457) \\
\end{array}$ & $\begin{array}{r}7,215 \\
(0.454) \\
\end{array}$ & $\begin{array}{r}7,477 \\
(0.460) \\
\end{array}$ \\
\hline
\end{tabular}

Note: All numbers are in thousands. See Appendix for sources. 
Table 4: Simulation Results

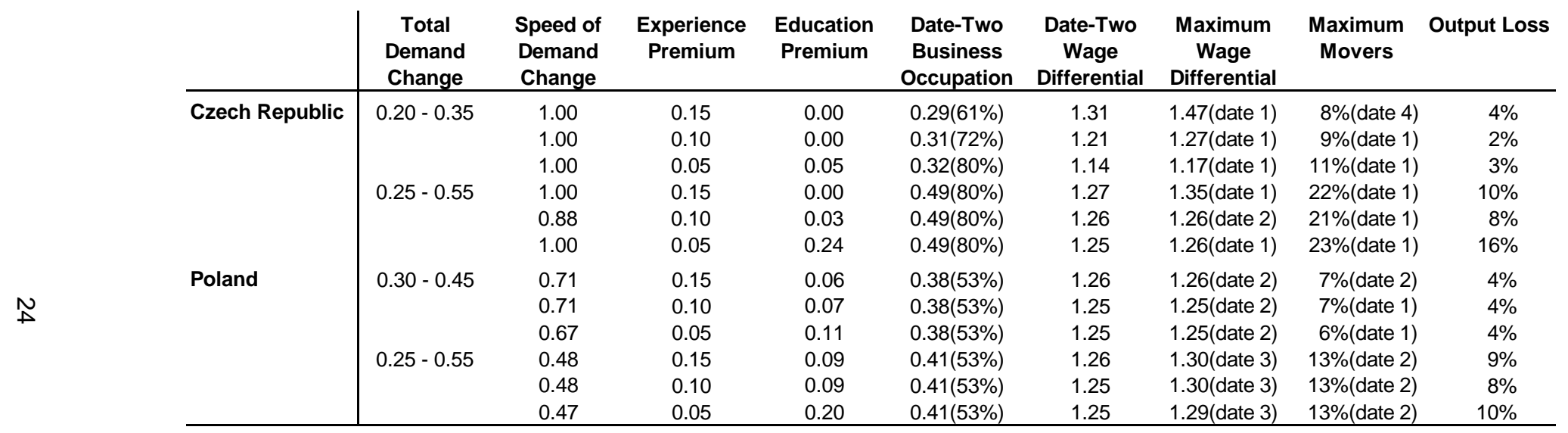

Explanatory notes: Total demand change: the initial and the long-run business share, $\mathrm{a}_{0}$ and $\mathrm{a}_{\omega}$ Speed of demand change: $p$

Experience premium: $\sigma_{1}$

Education premium: occupation-specific premium, $1 / \lambda-1$

Date-two business occupation: the share of business occupation, $\mathrm{n}_{2}$ and the reallocation as a percentage of total demand change, $\left(\mathrm{n}_{2}-\mathrm{n}_{0}\right) /\left(\mathrm{\alpha}_{\mathrm{w}}-\mathrm{a}_{0}\right)$

Date-two wage differential: the ratio of average wage rates (i.e., the wage bill divided by the number of workers) in the business and the technical occupations Maximum wage differential: the maximum and the date

Maximum movers: the maximum percentage of workers working in the business occupation with a technical education and the date

Output loss: The discounted sum of gaps between the actual output and the output under no mismatch problem, as a percentage of date 0 output 
Figure 1: Business Education Share

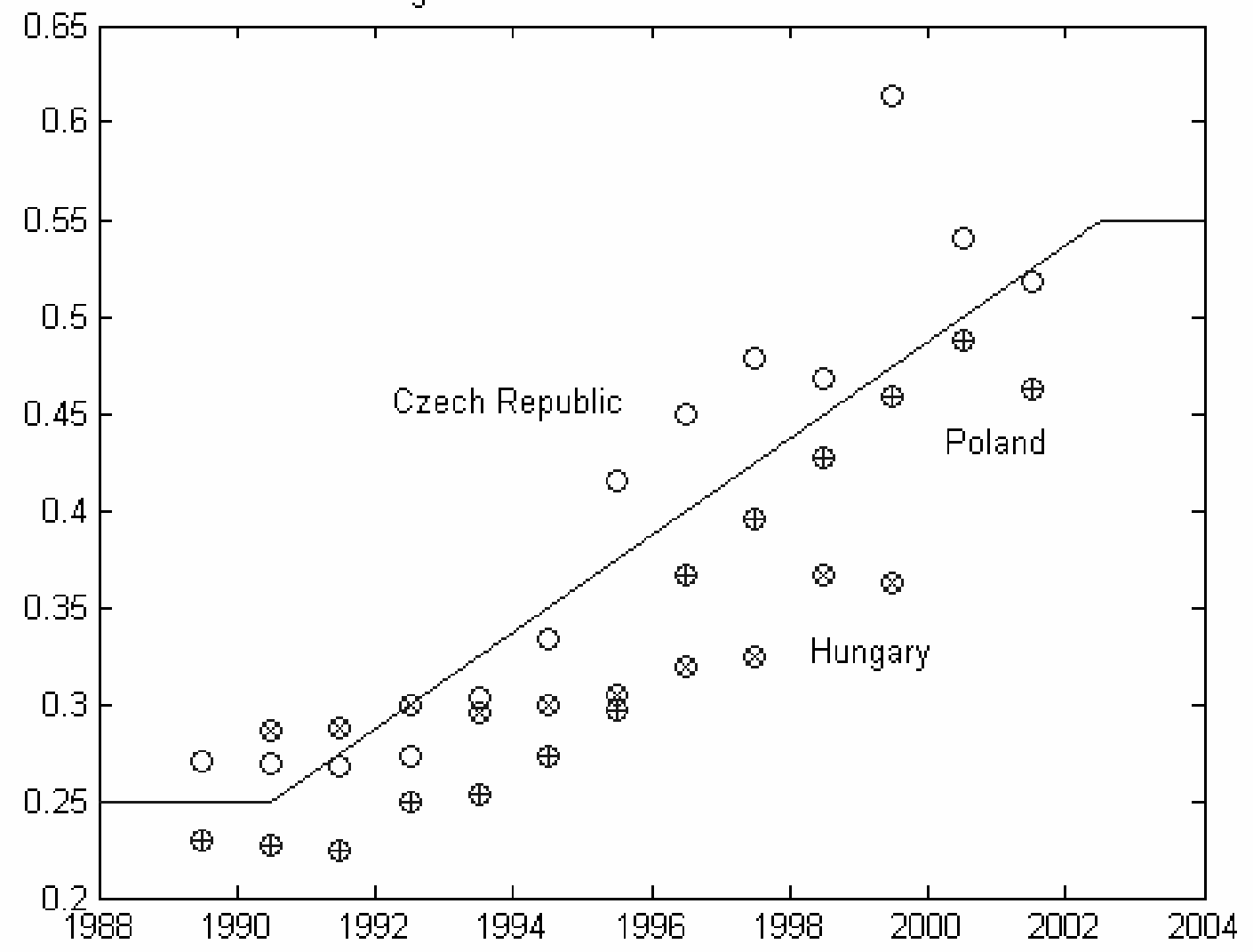


Figure 2: Business Occupation Share

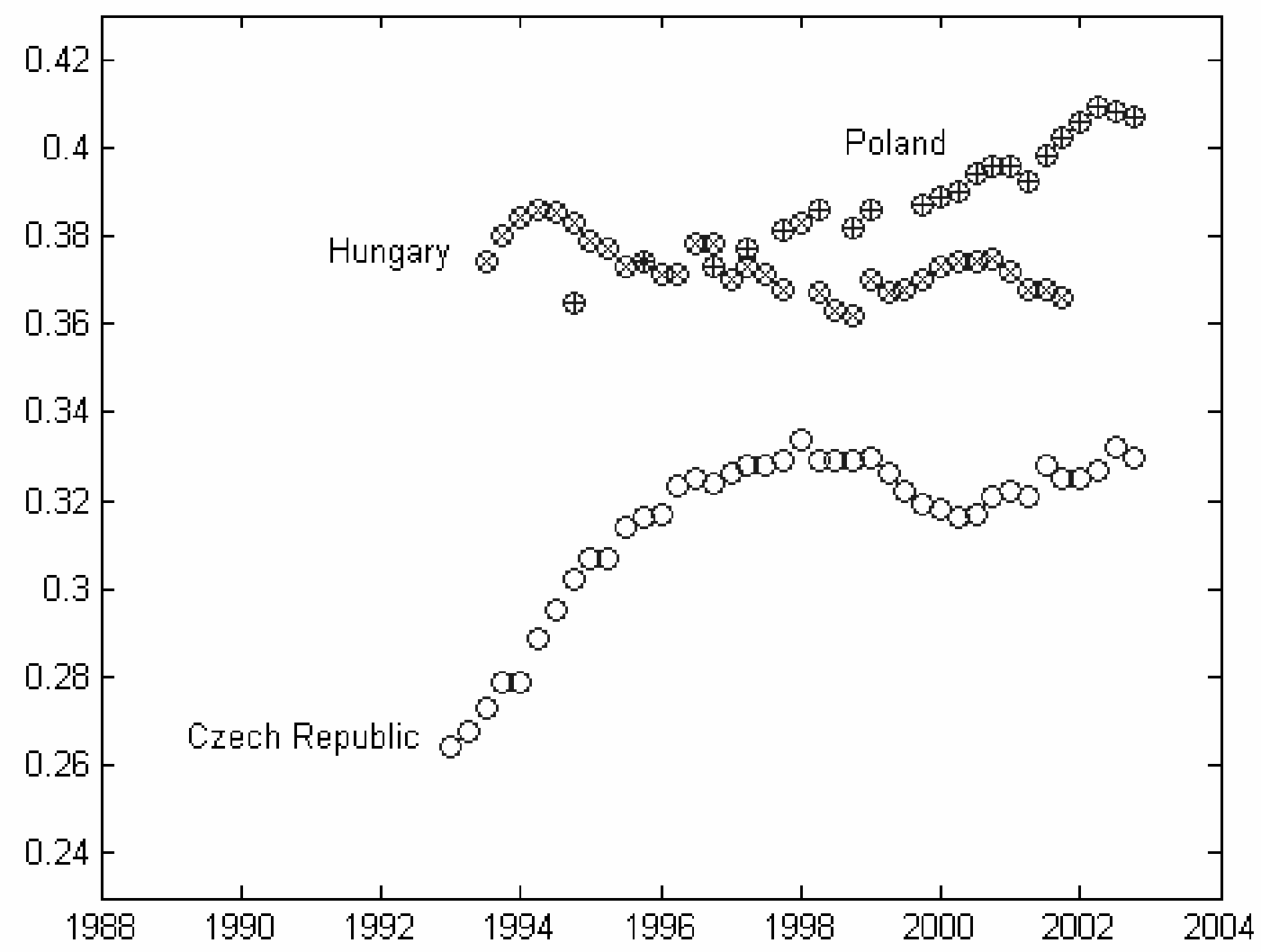


Figure 3: Business Occupation Share in Other European Countries

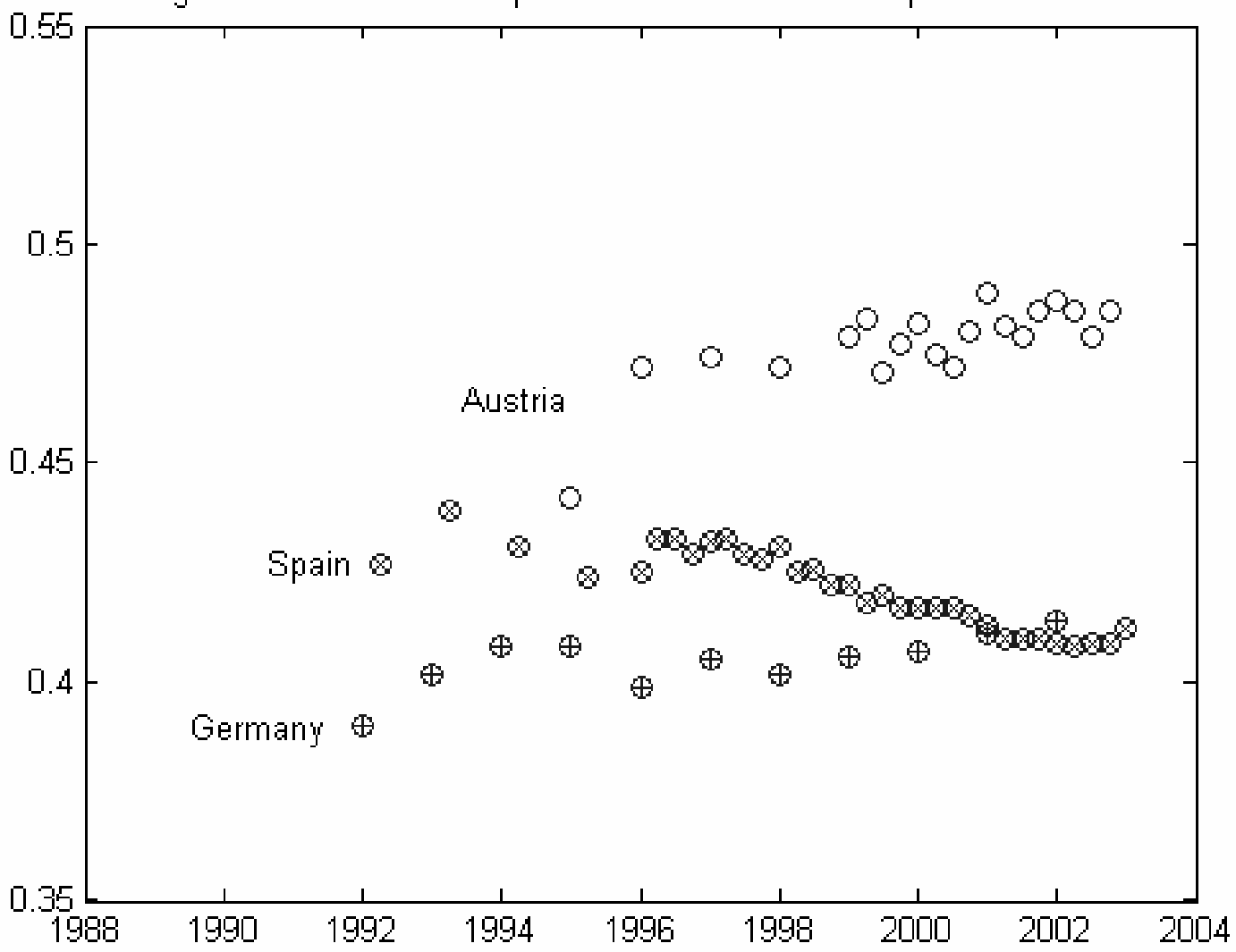


Individual researchers, as well as the on-line and printed version of the CERGE-EI Working Papers Series (including their dissemination) were supported from the following institutional grants:

- Economic Aspects of EU and EMU Entry [Ekonomické aspekty vstupu do Evropské unie a Evropské měnové unie], No. AVOZ70850503, (2005-2010);

Specific research support and/or other grants the researchers/publications benefited from are acknowledged at the beginning of the Paper.

(c) Byeongju Jeong, Michal Kejak, Viatcheslav Vinogradov, 2005

All rights reserved. No part of this publication may be reproduced, stored in a retrieval system or transmitted in any form or by any means, electronic, mechanical or photocopying, recording, or otherwise without the prior permission of the publisher.

Published by Charles University in Prague, Center for Economic Research and Graduate Education (CERGE) and

Economics Institute (EI), Academy of Sciences of the Czech Republic

CERGE-EI, Politických vězňu 7, 11121 Prague 1, tel.: +420 224005 153, Czech Republic.

Printed by CERGE-EI, Prague

Subscription: CERGE-El homepage: http://www.cerge-ei.cz

Editors: Directors of CERGE and EI

Managing editors: Deputy Directors for Research of CERGE and EI

ISSN 1211-3298

ISBN 80-7343-041-X (Univerzita Karlova v Praze, CERGE)

ISBN 80-7344-030-X (Národohospodáŕský ústav AV ČR, Praha) 
CERGE-EI

P.O.BOX 882

Politických vězňů 7

11121 Praha 1

Czech Republic http://www.cerge-ei.cz 